\title{
IMPELMENTASI KURIKULUM MUATAN LOKAL DALAM MENCAPAI TARGET HAFALAN AL-QUR'AN 4 JUZ DI SD ISLAM ANNAJAH JAKARTA BARAT
}

\author{
Fatimah \\ Sri Tuti Rahmawati \\ Institut Ilmu Al-Qur'an Jakarta \\ fatimah@gmail.com \\ sritutirahmawati@iiq.ac.id
}

\begin{abstract}
Abstarct
Many problems faced by the memorizers of the Qur'an such as not being able to memorize correctly according to makhraj and tajwid, there are still many students who have not memorized it perfectly, lack of dividing time in rote repetition, not focus on memorization, That is why it is not easy to memorize the Qur'an. This study aims to determine and describe how the concepts, implementation, evaluation and inhibiting and supporting factors in the Implementation of Local Content Curriculum in achieving the target of memorizing Al-Qur'an 4 juz at SD Islam Annajah West Jakarta. The object of this research is the Principal, Chairperson of the Tahfiz Coordinator, Tahfiz Teachers and students SD Islamic Annajah West Jakarta. Data collection techniques used are interviews, observation and documentation. The steps taken are data reduction, data presentation and conclusion drawing. The results of this study indicate that: (1) The concept of the Tahfiz Al-Qur'an Local Content Curriculum in class I is that students are focused on learning to read the Qur'an and memorizing the surah-An-Nas to Al-Fil, class II is memorizing Al-Qur'an juz 30, class III is memorizing Al-Qur'an juz 29, class IV is memorizing Al-Qur'an juz 28, class $V$ is me-morizing Al-Qur'an juz 27 and for class 6 repeating all memorization from juz 27-30. (2) The implementation of tahfidz is conducted every Monday-Friday. Before students add new memorization ustad / ustadzah recite the verse first, After that students follow together. For students who have memorized it directly deposit the memorization one by one. (3) The evaluation is carried out in several stages in 1 year, namely PTS 1, PAS 1 and PTS 2, PAT 2. Exams are conducted for 3 days, namely Monday, Tuesday and Wednesday. (4) Supporting factors in implementing this program are age, teacher criteria, motivation from parents and teachers, facilities and infrastructure. While the inhibiting factors in implementing the tahfidz program are students, lack of time management, and forgetfulness.
\end{abstract}

Keywords: Local Content Curriculum, memorizing Al-Qur'an

\begin{abstract}
ABSTRAK
Banyak masalah yang dihadapi penghafal Al-Qur'an seperti belum bisa menghafal dengan benar sesuai makhraj dan tajwidnya, masih banyak siswa yang belum menghafal secara sempurna, kurangnya membagi waktu dalam mengulang, tidak fokus dalam menghafal, Itulah sebabnya tidak mudah dalam menghafal Al-Qur'an. SD Islam Annajah merupakan Cabang dari Pesantren Hidayatunnajah, Bekasi. Penelitian ini merupakan penelitian kualitatif. Jenis penelitian yang digunakan adalah deskriptif. Objek penelitian ini adalah Kepala Sekolah, Ketua Koordinator Tahfiz, Guru-guru tahfiz dan peserta didik SD Islam Annajah Jakarta Barat. Teknik pengumpulan data yang digunakan yaitu wawancara, observasi dan dokumentasi. Tahap yang ditempuh yaitu reduksi data, penyajian data dan penarikan kesimpulan. Hasil dari penelitian ini menunjukan bahwa: (1) Konsep Kurikulum Muatan Lokal Hafalan Al-Qur'an di kelas I yaitu siswa difokuskan untuk belajar membaca Al-Qur'an dan menghafal surah AnNas sampai Al-Fil, kelas II yaitu menghafal Al-Qur'an juz 30, kelas III yaitu menghafal Al-Qur'an juz 29, kelas IV yaitu menghafal juz 28, kelas V menghafal Al-Qur'an juz 27 dan untuk kelas VI yaitu mengulang seluruh hafaln dari juz 27-30. (2) Pelaksanaan tahfiz ini dilakukan setiap hari senin-jumat. Sebelum siswa menambah hafalan baru ustadatau ustadzah mentalqinkan (membacakan) ayat tersebut terlebih dahulu, Setelah itu siswa mengikuti bersamasama. Bagi siswa yang sudah hafal langsung menyetorkan hafalannya satu per satu. (3) Evaluasi dilakukan menjadi beberapa tahap dalam 1 tahun yaitu PTS 1,PAS 1 dan PTS 2, PAT 2. Ujian dilakukan selama 3 hari yaitu hari Senin, Selasa dan Rabu. (4) Faktor pendukung dalam pelaksanaan program ini adalah usia, kriteria guru, motivasi dari orang tua dan guru, sarana dan prasarana. Sedangkan faktor penghambat dalam pelaksanaan program tahfiz adalah murid, kurang dapat mengatur waktu, dan lupa.
\end{abstract}

Kata Kunci: Kurikulum Muatan Lokal, Hafalan Al-Qur'an

15 | Fatimah dan Sri Tuti Rahmawati: Implementas Muatan Lokal dalam, ... 


\section{A. PENDAhuluan}

Al-Qur'an juga adalah kalamullah yang diturunkan dengan berbahasa Arab, yaitu satusatunya bahasa yang terjaga dengan baik dan Allah telah memberikan jaminan tentang kesucian dan kemurnian Al-Qur'an selama-lamanya. Setiap kalimat atau untaian Al-Qur'an telah dijadikan Allah untuk mudah dihafal dan dipahami oleh para penghafalnya. Allah telah membuktikan dengan ada huffazh (para pengahafal Al-Qur'an) diantara kita.

Di zaman sekarang sudah banyak para penghafal Al-Qur'an dari yang muda sampai yang tua. Setiap orang pasti bisa menghafal Al-Qur'an tetapi tidak semua orang bisa menghafal dengan baik. Banyak masalah yang dihadapi penghafal Al-Qur'an terkadang masih banyak sekali yang belum bisa menghafal dengan benar sesuai makhraj dan tajwidnya, minat siswa yang kurang dalam menghafal, dan masih banyak siswa yang belum menghafal secara mutkin, kurangnya membagi waktu dalam mengulang. Itulah sebabnya tidak mudah dalam menghafal Al-Qur'an, terkadang diperlukan juga metode-metode khusus ketika menghafalkannya dengan harapan setelah di hafal, hafalan tersebut tidak cepat lupa atau hilang dari ingatan.

Tidak semua penghafal Al-Qur'an menghafal 30 juz, tetapi ada juga yang menghafal hanya beberapa juz atau per juz saja. Walaupun begitu kehadiran mereka patut kita syukuri dan kita banggakan. Kegiatan menghafal Al-Qur'an atau dikenal dengan tahfiz Al-Qur'an itu sangat mempengaruhi kecerdasan alam berpikir. Otak manusia seperti kumparan dalam mesin listrik. Karena ketika menghafal ayat-ayat Al-Qur'an, kumparan tersebut terus berjalan mengaktifkan sel-sel dalam otak. Hal ini bermanfaat untuk mengolah data dalam otak. Apalagi jika materinya Kalamullah yang sangat mulia, tentu hasilnya akan sangat berbeda dibandingkan menghafal teori yang lain. ${ }^{1}$

SD Islam Annajah menerapkan program tahfiz Al-Qur'an dan tahfiz Al-Hadits sebagai program unggulan dalam bentuk pengimplementasian muatan lokal yang dibuat oleh pihak pesantren hidayatunnajah pebayuran, Bekasi. Muatan lokal tahfiz Al-Qur'an di SD Islam Annajah sudah berjalan sejak tahun 2009. Semua siswa wajib mengikuti program menghafal Al-Qur'an ini. Program hafalan Al-Qur'an yang diterapkan di SD Islam Annajah sebanyak 4 juz. Tahun-tahun sebelumnya SD Islam Annajah menerapkan target pertahun 2 juz namun karena faktor keluhan dari orang tua murid yang merasa kasihan terhadap anaknya karena sudah menerapkan full day school dan ditambah program tahfiz yang terlalu banyak jadi diubahlah kebijakan dan programnya. Adapun dalam pelaksanaannya untuk kelas 1 lebih difokuskan agar siswa mampu membaca Al-Qur'an sesuai dengan tawidnya dengan menggunakan metode nurul bayan memakai kitab fatturahman dan untuk hafalannya hanya sebatas surat An-Nas sampai surat Al-Fil. Untuk kelas 2 target yang harus dicapai adalah juz 30, kelas 3 target yang harus dicapai juz 29, kelas 4 target yang harus dicapai juz 28, kelas 5 target yang harus dicapai juz 27 dan untuk kelas 6 yaitu mengulang hafalan Al-Qur'an dari juz 27-30.

Adanya muatan lokal tahfiz Al-Qur'an bertujuan agar anak lebih dekat dengan Al-Qur'an dan lebih sering berinteraksi dengan Al-Qur'an sehingga anak lebih mudah diarahkan kepada

\footnotetext{
${ }^{1}$ Ahsin Sakho Muhammad, Menghafal Al-Qur'an, (Jakarta: Qaf, 2018), Cet. Ke-2, h. 22 16 | Fatimah dan Sri Tuti Rahmawati: Implementas Muatan Lokal dalam, ...
} 
kebaikan. Ketika anak sudah terbiasa menghafal Al-Qur'an, maka anak juga akan mudah menangkap dan mengingat pelajaran. Di dalam pelaksanaan tersebut juga diperlukan upaya dari pihak sekolah untuk menunjang pelaksanaan kegiatan menghafal siswa, dan juga diperlukan dorongan dari berbagai pihak agar siswa mampu mencapai target hafalan sesuai yang telah ditetapkan. Tetapi pada kenyataannya dalam melaksanakan program tahfiz AlQur'an ini masih terdapat banyak permasalahan serta hambatan. Hal tersebut dapat dilihat dari segi fasilitas, tenaga pendidik, siswa, maupun pada pelaksanaannya.

Guru yang dibutuhkan untuk membimbing siswa dalam menghafal Al-Qur'an tentunya harus disesuaikan dengan bidangnya agar pe-laksanaan program hafalan tersebut sesuai dengan tujuan dan harapan. Guru pembimbing menghafal tentunya diharapkan guru yang memang kompeten di bidang hafalan Al-Qur'an. Tentunya banyak faktor yang menyebabkan hal tersebut terjadi, baik dari tingkat kemampuan menghafal Al-Qur'an setiap anak yang berbeda-beda, kurangnya motivasi siswa dalam menghafal Al-Qur'an, kurangya minat siswa dalam menghafal Al-Quran dan lain-lain.

\section{B. METODOLOGI PENELITIAN}

Penelitian ini merupakan penelitian kualitatif. Jenis penelitian yang digunakan adalah penelitian kaulitatif deskriptif. Adapun objek dalam penelitian ini adalah Kepala Sekolah, Ketua Koordinator Tahfiz, Guru-guru tahfiz dan peserta didik SD Islam Annajah Jakarta Barat. Kemudian, teknik pengumpulan data yang digunakan dalam penelitian yaitu wawancara, observasi dan dokumentasi. Tahap selanajutnya dalam penelitian ini yaitu menggunakan teknik analisis data Miles dan Huberman. Tahap yang ditempuh yaitu reduksi data, penyajian data dan penarikan kesimpulan.

\section{PEMBAHASAN}

\section{Pengertian Implementasi Kurikulum}

Implementasi adalah suatu proses penerapan-penerapan, ide, konsep, atau inovasi dalam suatu tindakan praktis sehingga memberikan dampak yang baik berupa perubahan pengetahuan, keterampilan, maupun nilai dan sikap. Sedangkan "kurikulum adalah suatu program pendidikan yang berisikan bahan ajar atau pengalaman belajar yang diprogramkan, direncanakan dan dirancangkan secara sistemik atas dasar norma-norma yang berlaku yang dijadikan pedoman dalam proses pembelajaran bagi tenaga kependidikan dan peserta didik untuk mencapai tujuan pendidikan". ${ }^{2}$

implementasi kurikulum adalah penerapan atau pelaksanaan program kurikulum yang telah dikembangkan dalam tahap sebelumnya, kemudian diujicobakan dengan pelaksanaan dan pengelolaan, sambil senantiasa dilakukan penyesuaian terhadap situasi

${ }^{2}$ Dakir, Perencanaan Dan Pengembangan Kurikulum, (Jakarta: Rineka Cipta, 2010), h. 3 17 | Fatimah dan Sri Tuti Rahmawati: Implementas Muatan Lokal dalam, ... 
lapangan dan karakteristik peserta didik, baik perkembangan intelektual, emosional serta fisiknya. ${ }^{3}$

Jadi dapat disimpulkan bahwa implementasi kurikulum adalah suatu proses penerapan konsep, ide, program dalam kurikulum ke dalam praktek pembelajaran sehingga peserta didik menguasai kompetensi sebagai hasil interaksi dengan lingkungan.

\section{Kurikulum Muatan Lokal}

Kurikulum muatan lokal pada hakikatnya merupakan suatu perwujudan pasal 38 ayat 1 Undang-Undang Sitem Pendidikan Nasional (SISDIKNAS) yang berbunyi "pelaksanaan kegiatan pendidikan dalam satuan pendidikan didasarkan atas kurikulum yang berlaku secara nasional dan kurikulum yang disesuaikan dengan keadaan serta kebutuhan lingkungan dan ciri khas satuan pendidikan". ${ }^{4}$

Muatan lokal adalah program pendidikan yang isi dan media penyampaiannya dikaitkan dengan lingkungan alam, lingkungan sosial, serta lingkungan budaya dan kebutuhan daerah, sedangkan anak didik di daerah itu wajib mempelajarinya. ${ }^{5}$ Penentuan isi dan bahan pelajaran muatan lokal didasarkan pada keadaan dan kebutuhan lingkungan, yang dituangkan dalam mata pelajaran dengan alokasi waktu yang beridiri sendiri. Adapun materi dan isinya ditentukan oleh satuan pendidikan, yang dalam pelaksanaannya merupakan kegiatan kurikuler untuk mengembangkan kompetensi yang sesuai dengan keadaan dan kebutuhan daerah. ${ }^{6}$ Dengan demikian, kita harus benar-benar memerhatikan karakteristik lingkungan daerah dan juga kebutuhan daerah tersebut dalam proses perencanaan kurikulum. ${ }^{7}$

Muatan lokal yang dikembangkan untuk meningkatkan potensi daerah atau keunggulan daerah misalnya mengacu pada surat Keputusan Gubernur/Walikota. Muatan lokal ini bersifat wajib diikuti semua siswa. Sedangkan muatan lokal yang dikembangkan $\mathrm{SD} / \mathrm{MI}$ berdasarkan ciri khas atau keunggulan SD/MI tersebut maka ditetapkan sendiri oleh masing-masing SD/MI dalam KTSP dan bisa bersifat pilihan bagi siswa. ${ }^{8}$ Muatan lokal yang dimaksud dalam penelitian ini adalah mata pelajaran tahfiz yang dimasukkan dalam kurikulum sekolah muatan lokal yang sudah diteliti oleh peneliti.

\footnotetext{
${ }^{3}$ Oemar Hamalik, Dasar-dasar Pengembangan Kurikulum, (Bandung: PT Remaja Rosdakarya, 2007), h. 238

${ }^{4}$ E. Mulyasa, Manajemen Berbasis Sekolah, (Bandung: PT Remaja Rosdakarya, 2012), h. 40

${ }^{5}$ Abdulllah Idi, Pengembangan Kurikulum Teori \& Praktik, (Jakarta: Rajawali Pers, 2016), Cet. Ke-2, h.

${ }^{6}$ E. Mulyasa, Kurikulum Tingkat Satuan Pendidikan, (Bandung: PT Remaja Rosdakarya, 2008), Cet.
} Ke-5, h. 273

7 Abdullah Idi, Pengembangan Kurikulum Teori \& Praktik,..., h. 205

${ }^{8}$ H. Muhaimin, dkk., Pengembangan Model Kurikulum Tingkat Satuan Pendidikan Pada Sekolah \& Madrasah,..., h. 233

18 | Fatimah dan Sri Tuti Rahmawati: Implementas Muatan Lokal dalam, ... 


\section{Tujuan Pelaksanaan Program Muatan Lokal}

Pelaksanaan muatan lokal juga bermaksud untuk mengembangkan sumber daya manusia yang ada di daerah itu sehingga dapat dimanfaatkan untuk kepentingan pembangunan daerah, sekaligus mencegah terjadinya depopulasi daerah itu dari tenaga produktif. ${ }^{9}$ Secara khusus, dapat dikatakan bahwa pelaksanaan program muatan lokal bertujuan:

a. Mengenal dan menjadi lebih akrab dengan lingkungan alam, sosial dan budayanya.

b. Memiliki bekal kemampuan dan keterampilan serta penge-tahuan mengenai daerahnya yang berguna bagi dirinya maupun lingkungan masyarakat.

c. Memiliki sikap dan perilaku yang selaras dengan nilai-nilai luhur budaya setempat dalam rangka menunjang pembangunan nasional.

Pelaksanaan muatan lokal di sekolah tidak akan berjalan lancar dan mendapatkan hasil optimal kalau tidak didukung oleh semua pihak yang ikut bertanggung jawab terhadap keberhasilan pendidikan, karena dalam pelaksanaan muatan lokal ada beberapa hal yang tidak mungkin dapat dilaksanakan sendiri oleh pihak sekolah, misalnya sarana-prasarana, narasumber dan juga biaya. Agar tercapainya program muatan lokal dengan baik pendidik dan kepala sekolah harus mengembangkannya sesuai dengan asas-asas pengembangan kurikulum yang berlaku serta mengikut sertakan masyarakat sekitar dalam pelaksanaan program tersebut. ${ }^{10}$

\section{Fungsi Muatan Lokal Dalam Kurikulum}

Sebagai komponen kurikulum, muatan lokal secara keseluruhan memiliki fungsi sebagai berikut:

a. Fungsi Penyesuaian

Sekolah merupakan komponen, sebab sekolah berada dalam lingkungan masyarakat. Oleh karena itu, program sekolah harus disesuaikan dengan lingkungan dan kebutuhan daerah dan masyarakat.

b. Fungsi Integrasi

Peserta didik adalah bagian dari integral masyarakat. Karena itu, muatan lokal merupakan proram pendidikan yang berfungsi mendidik pribadi-pribadi peserta didik agar dapat memberikan sumbangan kepada masyarakat dan lingkungannya atau berfungsi untuk membentuk dan mengintegrasi pribadi peserta didik dengan masyarakat. ${ }^{11}$

c. Fungsi Perbedaan

Peserta didik yang satu dengan yang lain berbeda. Pengakuan perbedaan berarti memberi kesempatan bagi setiap pribadi untuk memilih apa yang yang sesuai dengan minat, bakat dan kemampuannya.

\footnotetext{
${ }^{9}$ Abdullah Idi, Pengembangan Kurikulum Teori \& Praktik,..., h. 207

${ }^{10}$ Abdullah Idi, Pengembangan Kurikulum Teori \& Praktik,..., h. 208

${ }^{11}$ E. Mulyasa, Kurikulum Tingkat Satuan Pendidikan..., h. 276
}

19 | Fatimah dan Sri Tuti Rahmawati: Implementas Muatan Lokal dalam, ... 


\section{Hafalan Al-Qur'an}

\section{a. Hafalan Al-Qur'an}

Menghafal berasal dari kata "hafal" yang berarti "telah masuk dalam ingatan atau dapat mengucapkan di luar kepala". Tahfiz berarti menghafal. Kata tahfiz berasal dari kata hafazha-yahfazhu-hafazhan yang berarti menghafal. ${ }^{12}$ Menurut Abdul Aziz Abdul Ra'uf, definisi menghafal adalah "proses mengulang sesuatu, baik dengan membaca atau mendengar". ${ }^{13}$

Sedangkan Al-Qur'an secara etimologi berasal dari kata qara'a-yaqra'u, qur'an yang berarti bacaan atau yang dibaca. ${ }^{14} \mathrm{Al}-\mathrm{Qur}$ 'an adalah bentuk mashdar dari qara'a yang artinya bacaan. Qara'a juga berarti mengumpulkan atau menghimpun. Sesuai namanya Al-Qur'an juga berarti himpunan huruf-huruf dan kata-kata dalam suatu ucapan yang rapi. ${ }^{15}$

"Al-Qur'an adalah firman Allah yang merupakan mukjizat (dapat melemahkan penantang Rasul) yang diturunkan kepada Nabi Muhammad SAW melalui malaikat Jibril AS, yang ditulis di mushaf, dinukil secara mutawattir, dan membacanya merupakan suatu ibadah, diawali dari surah Al-Fatihah dan diakhiri dengan surah An-Nas". ${ }^{16}$

Jadi dapat disimpulkan bahwa hafalan Al-Qur'an adalah usaha untuk menghafalkan ayat-ayat Al-Qur'an menggunakan ingatan dengan menyimpannnya dalam memori otak dan kemudian mengulang kembali ayat-ayat yang telah dihafal tanpa melihat Al-Qur'an kembali.

\section{b. Keutamaan Menghafal Al-Qur'an}

Menghafal Al-Qur'an merupakan suatu keutamaan yang besar dan posisi itu selalu didambakan oleh semua orang yang benar, seorang yang bercita-cita tulus, serta berharap pada kenikmatan duniawi dan ukhrawi agar manusia menjadi warga Allah dan dihormati dengan penghormatan yang sempurna. Kenikmatan menghafal Al-Qur'an tidak mudah dirasakan bagi orang yang belum terlatih dibutuhkan pembiasaan dan pelatihan secara terus-menerus untuk dapat merasakannya. Apabila iman penghafal Al-Qur'an kuat maka akan mendapatkan kenikmatan tersebut. ${ }^{17}$ Berikut ini adalah keutamaan membaca dan menghafal Al-Qur'an:

a. Al-Qur'an menjanjikan kebaikan, berkah dan kenikmatan bagi penghafalnya.

\footnotetext{
${ }^{12}$ Balai Litbang Agama Jakarta, Membumikan Peradaban Tahfidz Al-Qur'an, (Jakarta: Balai Penelitian dan Pengembangan Agama Jakarta), Cet. Ke-1, h. 23

${ }^{13}$ Abdul Aziz Abdul Ra'uf, Kiat Sukses Menjadi Hafizh Qur'an Dai'yah, (Bandung: PT Syamil Cipta Media, 2004), Cet. Ke-4, h.49

${ }^{14}$ Irfan Abdul Azhim, Agar Bacaan Qur'an Anda Tak Sia-Sia, (Solo: Pustaka Iltizam, 2009), h. 20

${ }^{15}$ Zaki Zamani, Syukron Maksum, Metode Cepat Menghafal Al-Qur'an, (Yogyakarta: Al Barokah, 2014), h. 13

${ }^{16}$ Muhaimin Zen, Tahfidz Al-Qur'an Metode Lauhun, (Jakarta: Transpustaka, 2013), h. 8

${ }^{17}$ Deden M. Makhyaruddin, Rahasia Nikmatnya Menghafal Al-Qur'an, (Jakarta: Noura Books, 2013),
} Cet. Ke-1, h. 127

20 | Fatimah dan Sri Tuti Rahmawati: Implementas Muatan Lokal dalam, ... 
b. Seorang hafizh Qur'an adalah orang yang mendapat Tasyrif Nabawi (penghargaan khusus dari Nabi).

c. Al-Qur'an akan menjadi penolong (syafaat) bagi para penghafalnya.

d. Orang yang menghafal Al-Qur'an akan meninggikan derajat manusia di surga.

e. Orang yang menghafal Al-Qur'an akan bersama para malaikat yang mulia dan taat.

f. Orang yang menghafal Al-Qur'an akan beruntung dalam perdagangannya dan tidak akan rugi. ${ }^{18}$

g. Orang yang menghafal Al-Qur'an akan mendapatkan kedudukan yang tinggi dalam pandangan Allah.

h. Penghafal Al-Qur'an yang menjunjung nilai Al-Qur'an akan dijuluki dengan "Ahlullah" atau keluarga Allah atau orang yang dekat dengan Allah.

i. Nabi menjanjikan bahwa orang tua penghafal Al-Qur'an akan diberi mahkota oleh Allah pada hari kiamat nanti.

j. Penghafal Al-Quran yang selalu mengulang hafalannya akan bermanfaat bagi kesehatan otak urat saraf lainnya. ${ }^{19}$

\section{c. Hukum Menghafal Al-Qur'an}

Memelihara Al-Qur'an pada dasarnya adalah kewajiban kita sebagai umat Islam. Karena Al-Qur'an adalah hal pokok yang harus kita jaga kemurniannya. Orang yang memelihara Al-Qur'an diibaratkan seperti shalat yang harus dibaca tepat waktu dengan bacaan yang benar dan khusyuk. Para ulama sepakat bahwa hukum menghafal Al-Qur'an adalah fardu kifayah. Apabila diantara anggota masyarakat ada yang melaksanakannya maka bebaslah beban anggota masyarakat yang lainnya, tetapi jika tidak ada sama sekali, maka berdosalah semuanya. Prinsip fardu kifayah ini dimaksudkan untuk menjaga Al-Qur'an dari pemalsuan, perubahan dan pergantian seperti yang pernah terjadi terhadap kitab-kitab yang lain pada masa lalu. ${ }^{20}$

Jadi dapat disimpulkan bahwa menghafal Al-Qur'an sangatlah penting untuk menjaga Al-Qur'an dari pemalsuan, pergantian dan dari hal-hal yang tidak diinginkan. Hal ini berarti orang yang menghafal Al-Qur'an tidak boleh kurang dari jumlah mutawatir. semakin banyak seorang yang menghafal Al-Qur'an semakin banyak pula yang menjaganya. Seandainya seseorang tersebut lupa dengan ayat yang dihafalnya hukumnya itu tergantung bagaimana seseorang tersebut dalam menjaga hafalannya.

18 Abdul Aziz Abdul Ra'uf Al-Hafidz, Kiat Sukses Menjadi Hafizh Al-Qur'an Da'iyah, (Jakarta: Markaz Al-Qur'an, 2015), Cet. Ke.1, h. 51-54

${ }^{19}$ Ahsin Sakho Muhammad, Menghafal Al-Qur'an, (Jakarta: Qaf, 2018), Cet. Ke-2, h. 27-33

${ }^{20}$ Deden M. Makhyaruddin, Rahasia Nikmatnya Menghafal Al-Qur'an,..., h. 254 


\section{d. Metode Menghafal Al-Qur'an}

Metode merupakan cara untuk mencapai maksud yang diinginkan. Dalam menghafal Al-Qur'an setiap orang mempunyai metode dan cara yang berbeda-beda. Metode apapaun yang dipakai tidak akan terlepas dari pembacaan yang berulangulang sampai mengucapkannya tanpa melihat mushaf sedikitpun. Dengan penggunaan metode yang tepat juga akan memudahkan seseorang dalam menghafal Al-Qur'an. Menurut Sa'adulloh ada beberapa metode dalam menghafal Al-Qur'an antara lain yaitu:

a. Bin Nazhar, yaitu metode cara dengan membaca cermat ayat-ayat Al-Qur'an yang akan dihafal dengan melihat mushaf Al-Qur'an secara berulang-ulang.

b. Tahfizh, yaitu metode cara dengan menghafalkan sedikit demi sedikit ayat-ayat Al-Qur'an yang telah dibaca berulang-ulang secara bin nazhar tersebut.

c. Talaqqi, yaitu metode cara dengan menyetorkan atau memperdengarkan hafalan yang baru dihafal kepada seorang guru atau instruktur.

d. Takrir, metode cara dengan mengulang hafalan yang pernah dihafalkan kepada guru tahfizh agar hafalan yang pernah dihafal tetap terjaga dengan baik.

e. Tasmi, yaitu metode dengan cara memperdengarkan hafalan kepada orang lain baik perseorangan maupun berjamaah. ${ }^{21}$

f. Metode seluruhnya, yaitu membaca satu halaman dari baris pertama sampai baris terakhir secara berulang-ulang sampai hafal.

g. Metode bagian, yaitu orang yang menghafal ayat demi ayat, kalimat demi kalimat yang dirangkaikan sampai satu halaman.

h. Metode campuran, yaitu kombinasi antara metode seluruhnya dengan metode bagian. Mula-mula dengan membaca satu halaman berulang-ulang, kemudia pada bagian tertentu dihafal tersendiri. Kemudian diulang kembali secara keseluruhan. $^{22}$

\section{e. Faktor Pendukung Dalam Menghafal Al-Qur'an}

a. Faktor Kesehatan

Kesehatan merupakan salah satu faktor yang sangat penting bagi penghafal Al-Qur'an. Jika tubuh sehat maka proses menghafal akan menjadi lebih mudah dan cepat. Namun, bila tubuh tidak sehat maka akan sangat menghambat proses menghafal Al-Qur'an. ${ }^{23}$

b. Faktor Psikologis

Kesehatan yang diperlukan oleh orang yang menghafal al-Qur'an tidak hanya dari segi lahiriah, tetapi juga dari segi psikologisnya. Sebab orang yang Al-

${ }^{21}$ Sa'dulloh, 9 Cara Cepat Hafal Al-Qur'an,..., h. 55

${ }^{22}$ Muhaimin Zen, Tahfidz, Al-Qur'an Metode Lauhun,..., h. 56

${ }^{23}$ Wiwi Alawiyah Wahid, Cara Cepat \& Mudah Hafal Al-Qur'an,..., h. 139 
Qur'an membutuhkan ketenangan jiwa baik dari pikiran maupun hati. Bila banyak sesuatu yang difikirkan, proses menghafal pun jadi terganggu.

c. Faktor Kecerdasan

Salah satu anugerah dari Allah kepada manusia yang tidak dimiliki oleh mahluk lain adalah akal budi. Manusia diberi kekuatan untuk berpikir yang disebut dengan kecerdasan. ${ }^{24}$ Kecerdasan merupakan salah satu faktor pendukung dalam menjalani proses menghafal Al-Qur'an.

d. Faktor Usia

Usia juga termasuk faktor yang sangat memengaruhi seseorang dalam menghafal Al-Qur'an. Usia muda 5-23 tahun tentu merupakan saat yang tepat untuk menghafal Al-Qur'an dan belajar, karena daya ingat dan fisik masih sangat kuat. Seperti pepatah mengatakan:

e. Faktor Motivasi

Dalam menghafal Al-Qur'an, motivasi menjadi dasar yang amat penting untuk pencapaian keberhasilan tujuan dan efektivitas kegiatan dalam proses menghafal. Motivasi yang tinggi dari seorang penghafal Al-Qur'an akan membuat dirinya memiliki keinginan yang kuat untuk mengikuti dan menghargai kegiatan yang berhubungan dengan proses belajar. Faktor yang paling dominan dalam menentukan motivasi untuk menghafal Al-Qur'an adalah diri kita sendiri. Tetapi selain itu kita juga membutuhkan motivasi dari orang tua, keluarga dan kerabat. ${ }^{25}$

\section{f. Faktor Penghambat dalam Menghafal Al-Qur'an}

a. Tidak Menguasai Makhorijul Huruf

Salah satu faktor penghambat atau kesulitan dalam menghafal Al-Qur'an adalah karena bacaan yang tidak bagus baik dari segi makhorijul huruf, kelancaran membacanya ataupun tajwid. Hal ini sangat penting diketahui karena orang yang tidak menguasai makhorijul huruf dan ilmu tajwid akan mendapatkan kesulitan dan memakan waktu yang lama dalam menghafal AlQur'an.

b. Tidak Sabar

Sabar adalah kunci sukses untuk meraih cita-cita, termasuk cita-cita dan keinginan dalam menghafal Al-Qur'an, jika seseorang tidak sabar dalam menghafal Al-Qur'an maka proses tersebut akan terhambat. Jika proses menghafal dilakukan dengan tulus dan sabar, maka ayat-ayat yang dihafalkan akan terasa mudah.

c. Tidak Sungguh-sungguh

${ }^{24}$ Sa'dulloh, 9 Cara Cepat Hafal Al-Qur'an,..., h. 71

${ }^{25}$ Wiwi Alawiyah Wahid, Cara Cepat \& Mudah Hafal Al-Qur'an,..., h. 141

23 | Fatimah dan Sri Tuti Rahmawati: Implementas Muatan Lokal dalam, ... 
Seseorang akan mengalami kesulitan dalam menghafal Al-Qur'an jika tidak sungguh-sungguh dalam menjalankannya. Oleh karena itu seseorang tidak boleh setengah hati dalam menjalankannya agar mendapat kesuksesan di dunia maupun akhirat.

\section{ANALISIS DAN TEMUAN}

1. Konsep Kurikulum Muatan Lokal Dalam Mencapai Target Hafalan AlQur'an

\section{a. Latar Belakang Program Tahfiz}

Awal mula program muatan lokal tahfiz Al-Qur'an diterapkan oleh pihak pondok pesantren Hidayatunnajah yang berada di Bekasi. Berhubung SD Islam Annajah Jakarta ini merupakan cabang dari pondok pesantren, maka sekolah juga ikut menerapkan muatan lokal program tahfiz Al-Qur'an tersebut. Program ini termasuk dalam kurikulum muatan lokal. Muatan lokal yang terdapat di sekolah ini yaitu tahfiz Al-Qur'an dan tahfiz Al-Hadits, tetapi yang menjadi keunggulan di sekolah ini adalah tahfiz Al-Qur'an. Se-kolah ini telah menerapkan program tahfiz ini sejak tahun 2009.

Penetapan adanya program tahfiz Al-Qur'an ini sebagai ciri khas bahwa sekolah Islam itu harus mempunyai keunggulan yang berhubungan dengan AlQur'an dan As-Sunnah. Penetapan program tahfiz Al-Qur'an ini juga mengacu pada salah satu misi sekolah yaitu "Menyelenggarakan program menghafal AlQuran minimal 4 juz" dengan diadakannya program tahfiz ini mendidik anak supaya bisa membaca Al-Qur'an sesuai dengan kaidahnya dan anak bisa akrab dengan Al-Qur'an karena hanya Al-Qur'an lah pedoman dan pemberih hidayah bagi setiap umat.

\section{b. Tujuan Program Tahfiz}

Penetapan suatu program di setiap instansi ataupun sekolah pasti mempunyai tujuan dan manfaat tersendiri bagi pelaksana program. Adapun tujuan dalam penetapan program tahfiz Al-Qur'an di SD Islam Annajah sebagai berikut:

1) Untuk mengimplementasikan program muatan lokal sesuai keinginan sekolah

2) Agar siswa terampil dalam membaca Al-Qur'an sejak dini serta memahami tajwid dan makhrajnya.

3) Untuk mengamalkan pada siswa bahwa mempelajari Al-Qur'an itu sangat penting

4) Untuk membina, mendorong dan membimbing siswa agar mencintai $\mathrm{Al}$ Qur'an, memahami Al-Qur'an, mengamalkannya dengan cara menghafalkan ayat-ayat Al-Qur'an. Dengan menghafalkannya siswa juga bisa lebih dekat dengan Al-Qur'an dan menjadikan Al-Qur'an sebagai petunjuk bagi 
kehidupan sehari-hari. Menurut Ustad Lutfie selaku Kepala Sekolah mengatakan bahwa:

“Tujuannya adalah agar anak bisa terampil dalam membaca Al-Qur'an sejak dini. Setelah bisa membacanya barulah anak bisa menghafalnya dengan baik. Selain itu agar anak bisa mencintai Al-Qur'an, memahami Al-Qur'an, mengamalkan Al-Qur'an, dekat dengan Al-Qur'an, menjadikan Al-Qur'an sebagai petunjuk dan pedoman hidup. Sehingga apabila seseorang tersesat dan diingatkan oleh Al-Qur'an dia akan kembali dan hatinya tidak akan keras, imannya akan kuat dan jalannya InsyaAllah akan lurus karena AlQur'an merupakan mukjizat yang apabila seseorang mempelajarinya tidak rugi di dunia maupun diakhirat". ${ }^{26}$

Dari pernyataan di atas dapat disimpulkan bahwa tujuan utama sekolah menerapkan program tahfiz Al-Qur'an sebagai program unggulan agar siswasiswi terbiasa melafalkan huruf-huruf Al-Qur'an, tidak merasa asing dengan ayat-ayat Al-Qur'an, me-nanamkan sejak dini bahwa Al-Qur'an itu petunjuk bagi kita semua umat muslim.

\section{c. Konsep program tahfiz}

Kurikulum yang diterapkan di sekolah memakai kurikulum Diknas yaitu Agama Islam, PKN, Bahasa Indonesia, IPA, IPS, Olah Raga, Keterampilan. Karena sekolah ini sekolah swasta, maka kami diberikan kewenangan untuk tidak sepenuhnya mengikuti kurikulum pemerintah sehingga di bidang Pendidikan Agama Islam dipecahkan menjadi beberapa bagian yaitu Akidah, AlAdab Al-Islami, Sejarah islam, Fiqih.

Muatan lokal disini yaitu Bahasa Arab, Tahfiz Al-Qur'an, Tahfiz Hadits \& Doa, tajwid. Konsep muatan lokal tahfiz Al-Qur'an di kelas 1 hanya difokuskan supaya siswa dapat mengenal huruf dan pengucapan agar bisa membaca AlQur'an dan meng-hafal surat An-Nas sampai Al-Fiil. Untuk kelas 2 indikatornya menghafal juz 30, untuk kelas 3 indikatornya menghafal juz 29, untuk kelas 4 indikatornya menghafal juz 28, untuk kelas 5 indikatornya menghafal juz 27 dan untuk kelas 6 indikatornya mengulang semua hafalan dari juz 27-30.

\section{Pelaksanaan Kurikulum Muatan Lokal Hafalan Al-Qur'an}

\section{a. Persiapan Sebagai Guru Tahfiz}

Persiapan harus dilakukan sebelum memulai suatu kegiatan agar kegiatan yang diinginkan bisa berjalan dengan maksimal. Persiapan yang dilakukan guru tahfiz sebenarnya hanya dengan membuat RPP sesuai dengan kalender pendidikan dan pembagian tempat mengajar masing-masing. Akan tetapi RPP itu hanya formalitas saja karena setiap guru pasti mempunyai cara atau strategi

${ }^{26}$ Hasil Wawancara dengan Ustad Lutfhie sebagai kepala sekolah di SD Islam Annajah pada hari Rabu 10 April 2019 pukul 11.00 di Ruang Rapat Guru

25 | Fatimah dan Sri Tuti Rahmawati: Implementas Muatan Lokal dalam, ... 
tersendiri untuk memudahkan siswa dalam menghafal Al-Qur'an. Ustad Haris Fadilah selaku pengajar tahfiz SD Islam Annajah mengatakan bahwa:

"ya setiap guru di wajibkan membuat RPP. Tetapi tidak semua guru memakai runtutan program hafalan sesuai dengan RPP, karena target setiap anak berbeda-beda. Ada yang cepat dan ada yang terlambat. Jadi tergantung guru masing-masing dalam mengkondisikan hafalan anak-anak." 27

Dari pernyataan di atas dapat disimpulkan bahwa RPP yang dibuat masingmasing guru tidak sesuai dengan fakta saat berada di lapangan karena setiap siswa memiliki kekurangan dan kelebihan masing-masing dalam menghafal. Jadi tergantung kreativitas guru tahfiz masing-masing kelas dalam mengatur hafalan anak-anak agar mencapai target yang diinginkan.

\section{b. Metode yang Digunakan dalam Pembelajaran Tahfidz}

Metode yang dipakai dalam proses pembelajaran tahfiz di SD Islam Annajah ada beberapa macam yaitu metode nurul bayan, metode talqin, metode mura'jaah, dan metode setoran (talaqqi).

Metode nurul bayan adalah metode agar anak mampu dalam mebaca AlQur'an dan mengenal tajwidnya.

Metode Talqin adalah sebuah metode pembelajaran Al-Qur'an yang memadukan antara perbaikan bacaan (tahsin) dan hafalan(tahfidz). Metode ini bersifat teacher centris, dimana posisi guru sebagai sumber belajar dalam proses pembelajaran tahfidz. Penerapan metode ini dengan cara guru mencontohkan bacaan dengan sistematika dan pengulangan tertentu, lalu murid mengikutinya sampai menghasilkan bacaan atau hafalan baru sebagaimana yang dicontohkan.

Metode muraja'ah adalah mengulang kembali hafalan yang sudah pernah dihafalkan agar tidak lupa. Penerapannya yaitu siswa mengulang kembali hafalan tersebut baik secara sendiri atau bersama-sama.

Metode setoran (talaqqi) biasa disebut metode Musyafahah yang artinya belajar secara berhadapan dengan guru (face to face). Metode setoran ini juga untuk menilai seberapa jauh hafalan siswa. Ustad Soleh selaku ketua koordinator tahfiz dan pengajar tahfiz mengatakan bahwa:

"Metode yang digunakan untuk kelas 1 yaitu metode nurul bayan dengan menggunakan kitab fatturahman yang menjelaskan cara membaca Al-Qur'an beserta tajwidnya. Karena di kelas 1 hanya difokuskan agar peserta didik bisa membaca Al-Qur'an dan memahami tajwidnya. Untuk kelas 2-6 yaitu menggunakan metode talqin yaitu guru melafalkan ayat Al-Qur'an terlebih dahulu lalu peserta didik mengikutinya. Setelah itu metode muraja'ah yaitu

\footnotetext{
${ }^{27}$ Hasil Wawancara dengan Ustad Haris Fadilah sebagai pengajar tahfidz di SD Islam Annajah pada hari Selasa 18 Juni 2019 pukul 09.30 di Ruang Rapat Guru 26 | Fatimah dan Sri Tuti Rahmawati: Implementas Muatan Lokal dalam, ...
} 
mengulang hafalan sebelumnya yang sudah pernah dihafalkan secara bersamasama. Selanjutnya, metode setoran (talaqqi) yaitu peserta didik masing-masing menyetorkan hafalannya bagi yang sudah hafal". ${ }^{28}$

\section{c. Proses Pelaksanaan Pembelajaran Hafalan Al-Qur'an}

Pelaksanaan kegiatan pembelajaran adalah upaya yang dilakukan pendidik untuk merealisasikan rancangan yang telah disusun baik di dalam silabus maupun rencana pembelajaran. Proses pelaksanaan pembelajaran tahfiz yang dilakukan guru tahfiz pastinya berbeda-beda. Karena setiap guru mempunyai cara tersendiri dalam membimbing siswa menghafal. Walaupun di sekolah ini telah membuat silabus atau RPP, tetapi pada pelaksanaanya guru terkadang sulit menyesuaikan dengan RPP yang sudah ada. Pelaksanaan tahfiz ini dilakukan setiap hari senin-jum'at di kelas masing-masing. Berdasarkan data hasil wawancara dan observasi, proses pelaksanaan pembelajaran tahfiz di setiap kelas sebagai berikut:

1) Pelaksanaan tahfiz di kelas II dan III

Pelaksanaan tahfiz Al-Qur'an di kelas ini dimulai pukul 07.00-08.30. Kelas II menyetorkan hafalan juz 30, sedangkan kelas III menyetorkan hafalan juz 29. Tahapan awal sebelum kegiatan belajar di mulai ustad/ustadzah menyuruh ketua kelas untuk bersiap dan memimpin doa. Setelah itu ustad/ustadzah meminta siswa untuk bersama-sama muraja'ah hafalan sebe-lumnya. Hal tersebut dilakukan kurang lebih selama 30 menit.

Tahap kedua yaitu kegiatan menambah hafalan. Sebelum siswa menambah ayat baru, ustad/ustadzah mentalqinkan (membacakan) ayat yang ingin di hafal, setelah itu murid mengikutinya. Hal tersebut dilakukan berulang-ulang selama 15 menit tergantung panjang dan pendeknya suatu ayat. Ustad Haris Fadilah selaku pengajar tahfiz mengatakan: "secara teknisnya setiap ayat guru membacakan terlebih dahulu sesuai makhraj dan tajwidnya dan siswa mendengarkan dengan baik. Setelah itu baru siswa mengikuti bacaanya. Jika ayatnya pendek, langsung 2/3 ayat saya bacakan. Itu dilakukan tanpa berhenti selama 15 menit. Nanti saya tes per barisan untuk baca ayat tersebut atau menunjuk $3 / 4$ orang siswa untuk baca sendiri". ${ }^{29}$ Setelah itu barulah siswa menghafal secara mandiri. Bagi yang sudah hafal langsung menyetorkan kepada ustad/ustadzahnya. Berbeda dengan ustad Haris, Ustadzah Rani menyuruh anak muridnya untuk

${ }^{28}$ Hasil Wawancara dengan Ustad Soleh sebagai ketua koordinator tahfidz dan pengajar tahfidz di SD Islam Annajah pada hari Selasa 24 April 2019 pukul 13.30 di Ruang Rapat Guru

${ }^{29}$ Hasil Wawancara dengan Ustad Haris Fadilah sebagai pengajar tahfidz di SD Islam Annajah pada hari Selasa 24 April 2019 pukul 09.30 di Ruang Rapat Guru

27 | Fatimah dan Sri Tuti Rahmawati: Implementas Muatan Lokal dalam, ... 
menambah hafalan dirumah sambil dibimbing orang tua, jadi ketika di sekolah hanya menyetorkan hafalan baru. ${ }^{30}$

2) Pelaksanaan tahfiz di kelas IVdan V

Pelaksanaan tahfiz Al-Qur'an di kelas ini dimulai pukul 10.00-11.30. Kelas IV menyetorkan hafalan juz 28, sedangkan kelas V menyetorkan hafalan juz 27. Tahapan awal sebelum kegiatan belajar di mulai ustad/ustadzah menyuruh ketua kelas untuk bersiap dan memimpin doa. Setelah itu ustad/ustadzah meminta siswa untuk bersama-sama memuraja'ah hafalan sebelumnya. Setelah selesai ustad/ustadzah mentalqinkan ayat baru yang ingin dihafal, lalu siswa mengikutinya. Hal tersebut dilakukan beberapa kali, setelah itu baru siswa mulai menghafal sendiri. Namun sebagian siswa ada yang langsung menyetorkan hafalan karna sudah mengahafal dirumah sebe-lumnya. Karena ada beberapa siswa ada yang sudah melebihi batas target yang telah ditentukan sekolah. Di kelas IV dan V semua siswa sudah bisa membaca Al-Qur'an dengan benar karena di kelas IV,V,VI mereka sudah mempelajari hukum tajwid. ${ }^{31}$ Walaupun begitu ustad/ustadzah tetap mentalqinkan ayat yang yang ingin disetorkan hari ini. ustadzah suci selaku pengajar tahfiz mengatakan: "pertama-tama saya mentahsin-kan ayat yang dihafal hari ini sebanyak 3 kali. Setiap saya membaca per ayat, anak-anak mengikutinya. Jika sudah selesai, mereka menghafal sendiri-sendiri. Lalu menyetorkan hafalannya kepada saya". ${ }^{32}$

3) Pelaksanaan tahfiz kelas VI

Pelaksanaan tahfiz Al-Qur'an di kelas ini dimulai pukul 10.00-11.30. kegiatan di kelas ini yaitu mengulang seluruh hafalan dari juz 27 sampai juz 30. Tahapan awal sebelum kegiatan belajar di mulai ustad/ustadzah menyuruh ketua kelas untuk bersiap dan memimpin doa. Tahapan kedua ustad menyuruh semua siswa untuk memurajaah hafalan selama 15-20 menit. Setelah selesai barulah siswa menghafal secara mandiri dan menyetorkan hafalannya kepada ustad. ${ }^{33}$

\section{d. Sistem Pelaporan kepada Orang Tua}

Setiap murid SD Islam Annajah harus mempunyai buku prestasi tahfiz. Buku tersebut digunakan untuk mencatat kegiatan proses menghafal siswa. Selain itu buku tersebut juga berguna untuk memberikan infromasi kepada orang tua siswa agar mengetahui proses anaknya dalam menghafal Al-Qur'an. Selanjutnya, guru-guru juga memanfaatkan gadget untuk melaporkan semua kegiatan di yang ada di SD Islam Annajah. Setiap guru tahfiz mempunyai grup

\footnotetext{
${ }^{30}$ Hasil observasi di kelas 2 dan 3 pada hari Selasa 18 Juni 2019 pada pukul 07.00-08.00

${ }^{31}$ Hasil observasi di kelas 4 dan 5 pada hari Selasa 18 Juni 2019 pada pukul 10.00-11.00

${ }^{32}$ Hasil Wawancara dengan Ustadzah Suci sebagai dan pengajar tahfidz di SD Islam Annajah pada hari Selasa 24 April 2019 pukul 11.30 di Ruang Rapat Guru

${ }^{33}$ Hasil observasi di kelas 6 pada hari Rabu 19 Juni 2019 pada pukul 10.00-11 28 | Fatimah dan Sri Tuti Rahmawati: Implementas Muatan Lokal dalam, ...
} 
WA untuk menjalin komunikasi antara kepala sekolah, ustad/ustadzah, orang tua siswa. Jadi jika ada masalah di dalam kelas, guru bisa langsung melaporkan kejadian tersebut di grup WA orang tua murid. Dari sini orang tua bisa mengontrol perkembangan anaknya setelah kegiatan belajar selesai.

\section{e. Program Tambahan}

Semenjak tahun ajaran 2018/2019 sekolah membuat program baru yaitu PR membaca Al-Qur'an yang dilakukan setiap hari dirumah. Jadi meskipun tidak dalam keadaan libur panjang siswa harus tetap membaca Al-Qur'an berserta artinya dirumah dan dipantau oleh orang tua masing-masing. Disini peran orang tua sangat diperlukan untuk memaksimalkan program tersebut. Guru juga bisa memantau seberapa jujur dan perhatiankah orang tua dengan anak.

Cara pembelajarannya yaitu sekolah membuat selembaran program membaca Al-Qur'an yang dibagikan kepada setiap masing-masing siswa dari kelas 2 sampai 6. Di dalam kertas tersebut sudah ditentukan surat apa yang harus di baca per harinya. Di dalam kertas tersebut berisi hari, tanggal, nama surat,penilaian orang tua atas bacaan siswa, paraf orang tua, paraf guru . Setelah 1 minggu diisi siswa diharuskan membawa kertas tersebut. Agar guru mengetahui apakah anak tersebut benar-benar membaca atau tidak.

\section{Teknik evaluasi dalam program hafalan AI-Qur'An}

Teknik evaluasi sangat penting dilakukan dalam setiap pembelajaran karena dengan evaluasi bisa mengetahui seberapa jauh perkembangan atau kemajuan hasil program tersebut.

Evaluasi dalam pembelajaran tahfiz di SD Islam Annajah dilakukan secara lisan berupa setor hafalan. Evaluasi ini dilakukan setiap 3 bulan sekali menjadi 4 tahap yaitu PTS 1 dan PAS 1 serta PTS 2 dan PAT 2. Pelaksanaan ujian dilakukan selama 3 hari yaitu hari senin, selasa dan rabu. Pelaksanaan ujian dilakukan di kelas masing-masing. Untuk kelas 2 sampai kelas 5 dalam 1 juz ujiannya dibagi menjadi 3 tahap. Setiap tahap anak-anak menyetorkan hafalan kurang lebih sebanyak 3 lembar setengah atau tergantung panjang dan pendeknya surat tersebut.

Sedangkan untuk kelas 6 yaitu Mengulang hafalan dari juz 27-30. Setiap 3 bulan sekali siswa menyetorkan ujian sebanyak 1 juz dalam jangka waktu 3 hari yaitu senin, selasa dan rabu. Evaluasi setiap harinya masing-masing siswa mempunyai buku prestasi tahfiz, agar guru dan orang tua mengetahui pencapaian siswa dalam meng-hafal Al-Qur'an. Untuk evaluasi program tahfiz yaitu dengan mengadakan rapat guru setiap 1 minggu sekali untuk mengetahui perkembangan hafalan siswa. Rapat guru dilaksanakan setiap hari kamis setelah jam sekolah 
selesai. Dengan rapat tersebut dapat mengetahui masalah-masalah yang terjadi dan mencari solusi untuk permasalahan tersebut.

\section{Faktor penghambat dan pendukung dalam program hafalan Al-Qur'an}

Menghafal Al-Qur'an merupakan suatu proses yang panjang dan membutuhkan konsentrasi yang tinggi. Oleh karena itu, menghafal Al-Qur'an membutuhkan minat dan motivasi yang tinggi bagi orang yang menghafalkannya. Dalam menghafal pasti membutuhkan suatu proses, tentunya banyak faktor yang mempengaruhinya. Faktorfaktor yang mempengaruhi pelaksanaan program tahfiz Al-Qur'an di SD Islam Annajah dikelompokkan menjadi dua kategori yaitu faktor pendukung dan penghambat. Adapun faktor pendukungnya antara lain:

a. Faktor Usia

Usia muda merupakan salah satu faktor penunjang untuk dapat mengahafal Al-Qur'an. Ada pepatah mengatakan, "belajar di waktu kecil ibarat mengukir di atas batu, dan belajar setelah dewasa ibarat mengukir di atas air". Makna dari pepatah tersebut bahwa faktor umur sangat mempengaruhi proses pembelajaran.

Usia anak-anak dan remaja atau usia antara tujuh sampai lima belas tahun merupakan masa yang mudah untuk menerima pengetahuan, termasuk untuk mampu menghafalkan Al-Qur'an. Masa anak-anak adalah masa paling tepat untuk menghafalkan Al-Qur'an.

Siswa SD Islam Annajah dapat dikategorikan usia muda menuju remaja. Hal itu dapat diketahui dari kisaran enam sampai dua belas tahun setingkat SD/MI. Dengan usia yang tergolong muda, tentu daya ingatnya pun lebih tinggi. Namun hal tersebut tidak menjadi jaminan karena kemampuan setiap siswa yang berbeda-beda.

\section{b. Kriteria Guru}

Seorang guru sangat mempengaruhi pelaksanaan program tahfiz Al-Quran. Kriteria/syarat seorang guru tahfiz juga berperan agar siswa menghafalkan suratsurat yang dihafal sesuai dengan target yang telah ditentukan. Ustad Luthfie sealaku kepala sekolah mengatakan:

"ya alhamdulillah beberapa guru tahfiz di sekolah ini ada yang sudah menyelesaikan hafalan 30 juz. Walaupun tidak semua guru tahfiz menyelesaikan hafalannya, akan tetapi setiap guru tahfidz diwajibkan untuk hafal 2-4 juz (juz2730) agar menyamai program sekolah. Sebenarnya banyak penghafal Al-Qur'an yang 30 juz, tetapi mencari guru yang benar-benar ikhlas untuk mendidik anak murid menjadi penghafal Al-Qur'an tanpa memikirkan penghasilan yang didapat itu sangat susah. Karena pada hakikatnya guru penghafal Al-Qur'an yang ikhlas dan tulus itu sangat susah. Jika guru itu mengajar hanya semata-mata mengincar materi yang didapatkan, anak didik tidak akan jadi". ${ }^{34}$

${ }^{34}$ Hasil Wawancara dengan Ustad Lutfhie sebagai kepala sekolah di SD Islam Annajah pada hari Rabu 10 April 2019 pukul 11.00 di Ruang Kepala Sekolah

30 | Fatimah dan Sri Tuti Rahmawati: Implementas Muatan Lokal dalam, ... 


\section{c. Motivasi dari Orang Tua dan Guru}

Orang tua sebagai pendidik utama di rumah tentu mengharapkan pendidikan yang terbaik untuk anaknya di sekolah. Peran dan dukungan orang tua murid sangat mempengaruhi semangat siswa dalam menghafal Al-Qur'an. Salah satu dukungan orang tua kepada anaknya dalam memotivasi menghafal Al-Qur'an seperti yang dikatakan Afifah siswi kelas 3A:

"mendukung banget, aku kalau malem hari selalu di ingatkan orang tua untuk menghafal dan pagi hari saat di perjalanan sambil menghafal juga ka. ${ }^{35}$

Salah satu dukungan orang tua kepada anaknya dalam memotivasi menghafal Al-Qur'an seperti yang dikatakan Fatih siswa kelas 4B:

"mendukung, biasanya di semangatin, terus dinasehatin jangan main-main terus. Kalo dinasehatin terus saya jadi semangat ka". ${ }^{36}$

Salah satu dukungan orang tua kepada anaknya dalam memotivasi menghafal Al-Qur'an seperti yang dikatakan Tursina siswa kelas 5A:

"Cara motivasi orang tua aku disemangatin, misalkan aku udah hafal surat baru biasanya aku dikasih hadiah. Dengan cara itu aku jadi lebih semangat menghafalnya ka." 37

Jadi dapat disimpulkan bahwa orang tua mempunyai cara tersendiri dalam mendukung dan memotivasi anaknya, ada yang diberi hadiah, ada yang dinasehatin, dan lain-lain. Akan tetapi yang terpenting peran dan motivasi yang diberikan orang tua untuk anaknya di SD Islam Annajah yaitu dengan menyimak hafalan siswa yang akan disetorkan keesokan harinya, memantau kegiatan PR membaca Al-Qur'an dirumah, memberikan nasihat yang positiv serta memberi semangat anaknya.

Selain itu motivasi dari guru juga sangat penting dalam membimbing siswa menghafal, selain memberikan tausiah dan arahan salah satu yaitu dengan memberikan apresiasi berupa poin atau bintang bagi siswa yang hafalannya bagus dan rajin. Seperti yang dikatan oleh ustadzah Rani:

"cara memotivasi saya dengan memberikan bintang kepada siswa dan saya catat bintang yang di dapatkan setiap siswa di buku harian. Nanti di akhir semester saya akan menghitungnya. Ada 3 juara yang mendapatkan bintang. Juara 1 bintang yang terbanyak, ada juara 2 dan juara $3 " .38$

\footnotetext{
${ }^{35}$ Hasil Wawancara dengan Afifah siswi SD Islam Annajah pada hari Selasa 18 Juni 2019 pukul 07.30 di Kelas 3A

${ }^{37}$ Hasil Wawancara dengan Tursina siswa SD Islam Annajah pada hari Selasa 18 Juni 2019 pukul 11.15

${ }^{36}$ Hasil Wawancara dengan Fatih siswa SD Islam Annajah pada hari Selasa 18 Juni 2019 pukul 10.30 di

${ }^{38}$ Hasil Wawancara dengan Ustadzah Rani sebagai pengajar tahfidz di SD Islam Annajah pada hari Senin 17 Juni 2019 pukul 09.30 di Kelas 2A
}

31 | Fatimah dan Sri Tuti Rahmawati: Implementas Muatan Lokal dalam, ... 
Berbeda dengan ustadzah rani, ustadzah suci memotivasinya dengan menceritakan semua pengalaman yang dialami dalam menghafal Al-Qur'an mengatakan:

"cara saya motivasi anak-anak dengan menceritakan pengalaman saya menghafal Al-Qur'an saat di pondok, karena persaingannya sangat ketat dan kita harus mempunyai bekal dari sekarang. lalu saya bilang jika kita ingin memberikan hadiah ke orang tua, ya harus menghafal Al-Qur'an". ${ }^{39}$

Jadi dapat disimpulkan bahwa setiap ustad/ustadzah mempunyai cara tersendiri dalam memberikan motivasi dan semangat kepada siswanya, ada yang memberikan reward bintang, ada yang menceritakan pengalamannya dan lain-lain. Dengan hal yang dilakukan ustad/ustadzah tersebut akan membuat siswa lebih semangat dan bersungguh sungguh dalam menghafal.

\section{d. Sarana dan Prasarana}

Sarana dan prasarana merupakan salah satu pokok yang menunjang keberhasilan kegiatan mengahafal siswa. Jika dilihat fasilitas yang diberikan oleh SD Islam Annajah cukup memadai. Hal itu terlihat dari ruang kelas yang ber-AC, meja belajar dan whiteboard, buku prestasi tahfdz, serta speaker di setiap kelas. Selain itu terbatasnya murid di kelas 3,4 dan 5 yaitu tidak lebih dari 20 siswa. Hanya kelas 2 saja yang lebih dari $20 \mathrm{siswa} / \mathrm{siswi}$. Dengan fasilitas yang mencukupi akan mempermudah dalam mencapai keberhasilan program tahfidz Al-Qur'an tersebut.

Sedangkan Faktor penghambat dalam program tahfidz Al-Qur'an di SD Islam Annajah antara lain:

a. Murid

Lingkungan kelas merupakan faktor yang mempengaruhi keberhasilan program. Yang menjadi faktor lingkungan kelas salah satunya yaitu teman. Teman yang baik akan selalu mengajak temannya menuju hal yang positif. Biasanya yang membuat anak-anak kurang fokus dalam menghafal karena sesama teman saling mengajak mengobrol atau bercanda. Akibatnya teman-teman yang lain jadi saling mengikuti. Karena itu untuk anak yang sering bercanda akan lebih baik di pisahkan tempat duduknya dan didekatkan dengan teman yang rajin, agar anak tersebut terbawa dengan teman yang rajin.

b. Kurang dapat mengatur waktu

Masa anak-anak dan remaja adalah masa bermain, sehingga waktunya banyak sekali terbuang. Anak harus mendapatkan pengawasan orang tua di rumah dan mendapatkan pengawasan guru di sekolah. Maka dari itu kerja sama dari guru dan orang tua sangat diperlukan. Keduanya harus saling bekerja sama dan berusaha semaksimal mungkin mengarahkan anak-anaknya ke hal yang positif.

\footnotetext{
${ }^{39}$ Hasil Wawancara dengan Ustadzah Suci sebagai dan pengajar tahfidz di SD Islam Annajah pada hari Selasa 24 April 2019 pukul 11.30 di Ruang Rapat Guru
}

32 | Fatimah dan Sri Tuti Rahmawati: Implementas Muatan Lokal dalam, ... 
Kegiatan belajar mengajar di SD Islam Annajah yaitu mulai pukul 07.00-14.15. Sekolah ini menerapkan full day school jadi harus membagi waktu juga untuk memuraja'ah hafalan sebelumnya. Musa siswa kelas 3B mengatakan:

"kadang-kadang, kalo lagi males mengulang hafalan biasanya aku dengerin murattal." 40

berbeda dengan Fatih siswa kelas 4B mengatakan:

" jarang ka, biasanya kalo mengulang itu di saat mau ujian baru aku bener-bener menghafal di rumah. kalo untuk setiap harinya kurang." 41

berbeda dengan Tursina siswa kelas 5A mengatakan:

"iya dirumah sering mengulang dan setornya ke umi. tapi gak setiap hari ka, terkadang aku juga agak sedikit bosen."42

Jadi dapat disimpulkan bahwa masalah yang dihadapi siswa dalam menghafal atau memurajaah karna kurangnya pantauan orang tua dalam mengatur waktu anak, karena anak usia SD adalah masa-masa bermain. Terkadang siswa hanya mengulang hafalan ketika waktu mau ujian. Mungkin bagi sebagian siswa yang kemampuan menghafalnya bagus akan lebih mudah dalam mengingat hafalan, akan tetapi bagi siswa yang kurang akan merasa sulit dalam menambah serta mengingat hafalan sebelumnya dan akibatnya menjadi lupa

c. Lupa

Lupa merupakan alasan yang sangat sering di denger guru ketika murid menyetorkan hafalan. Salah satu faktor lupa karna kurang fokus dalam menghafal, kurangnya minat siswa dalam menghafal, jarang mengulang hafalan. Ustad Haris Fadilah selaku pengajar tahfidz mengatakan:

"pertama bagi siswa yang bacaannya kurang lancar, kedua kemauan dari siswa itu sendiri, ketiga bimbingan dari orang tua, karena untuk menambah hafalan itu gampang, tetapi menjaganya yang susah, jadi jika peran orang tua tidak ada untuk memurajaah hafalan anaknya maka cepat hilang hafalan tersebut karena waktu terbanyak itu dirumah". ${ }^{43}$

Dari pernyataan di atas dapat disimpulkan bahwa faktor lupa adalah hal yang sering terjadi saat siswa menghafal Al-Qur'an. Pihak sekolah pun juga

\footnotetext{
${ }^{40}$ Hasil Wawancara dengan Musa siswa SD Islam Annajah pada hari Selasa 18 Juni 2019 pukul 09.00 di Kelas 3B Kelas 4B

${ }^{41}$ Hasil Wawancara dengan Fatih siswa SD Islam Annajah pada hari Selasa 18 Juni 2019 pukul 10.30 di

${ }^{42}$ Hasil Wawancara dengan Tursina siswa SD Islam Annajah pada hari Selasa 18 Juni 2019 pukul 11.15 di Kelas $5 \mathrm{~A}$

${ }^{43}$ Hasil Wawancara dengan Ustad Haris Fadilah sebagai pengajar tahfidz di SD Islam Annajah pada hari Selasa 24 April 2019 pukul 09.30 di Ruang Rapat Guru
}

33 | Fatimah dan Sri Tuti Rahmawati: Implementas Muatan Lokal dalam, ... 
sudah membagi waktu antara menambah dan mengulang hafalan. Akan tetapi waktu yang disediakan sekolah lebih terfokus kepada menambah hafalan. Karena waktu di sekolah tidak mencukupi jika harus memura-jaah semua surat yang sudah di hafal setiap harinya. Jadi bantuan orang tua dirumah sangat diperlukan agar siswa bisa menjaga hafalannya.

\section{E. KESIMPULAN}

Dari hasil penelitian ini maka dapat diambil kesimpulan bahwa pada kurikulum muatan lokal dalam mencapai target hafalan Al-Qur'an 4 juz di SD Islam Annajah sudah berjalan dengan baik walaupun belum sempurna secara maksimal. Pihak sekolah selalu berusaha untuk mengembangkan program ini agar terus meningkat menjadi lebih baik. Konsep hafalan yang diterapkan sekolah, setiap kelas mempunyai target yang berbedabeda yaitu pelaksanaan di kelas 1 hanya di fokuskan agar siswa bisa membaca Al-Qur'an memakai kitab fatturahman dengan menggunakan metode nurul bayan. Di kelas ini suratsurat yang wajib dihafal hanya surat An-Nas sampai surat Al-Fiil. Kelas 2 target yang harus dicapai juz 30, kelas 3 target yang harus dicapai juz 29, kelas 4 target yang harus dicapai juz 28, kelas 5 target yang harus dicapai juz 27 dan untuk kelas 6 target yang harus dicapai yaitu 4 juz mengulangan seluruh hafalan.

Selanjutnya perubahan metode yang yang digunakan kelas 1 dari metode Iqra berubah menjadi metode nurul bayan, lalu tambahan program baru yaitu PR membaca AlQur'an yang dilakukan siswa kelas 2-6, tambahan hafalan surah Al-Baqarah. Evaluasi program hafalan yang dilakukan sekolah yaitu setiap 3 bulan sekali, sedangkan evaluasi yang dilakukan untuk guru-guru setiap 1 minggu sekali.

Pelaksanaan program tahfidz Al-Qur'an di SD Islam Annajah sebenarnya sudah berjalan dengan cukup baik, namun tetap perlu adanya peningkatan agar semua tujuan yang diharapkan dapat tercapai secara maskimal. Adapun faktor-faktor yang mempengaruhi program tahfidz Al-Qur'an tersebut:

1. Faktor pendukung dalam penerapan program tahfidz Al-Qur'an di SD Islam Annajah adalah faktor usia, kriteria guru, motivasi dari orang tua dan guru, sarana dan prasarana. Semua faktor tersebut sangat mempengaruhi keberhasilan siswa dalam mencapai target hafalan yang diinginkan. Oleh karena itu faktor ini harus dipertahankan agar program tahfiz ini bisa berjalan dengan maksimal.

2. Faktor penghambat dalam penerapan program tahfidz Al-Qur'an di SD Islam Annajah adalah murid, kurang dapat mengatur waktu, dan lupa. Semua faktor ini juga sangat mempengaruhi dalam mencapai keberhasilan siswa. Oleh karenanya masing-masing siswa harus memiliki kesadaran masing-masing dan sebagai orang tua harus memantau dan mengarahkan anaknya agar mencapai target yang diinginkan. 


\section{F. DAFTAR PUSTAKA}

Ahmadi, Rulam, Metodologi Penelitian Kualitatif, Yogyakarta: Ar-Ruzz Media, 2014.

Al-Gazwini, Ibnu Majah Abu Abdullah Muhammad bin Yazid, Sunan Ibnu Majah, Riyadh: Darr As-Salam, t.t.

Al-Ghautani, Yahya bin Abdurrazzaq, Cara Mudah\&Cepat Menghafal Al-Qur'an, Jakarta: Pustaka Imam Asy-Syafi'i, 2018.

Al-Hafidz, Abdul Aziz Abdul Ra'uf, Kiat Sukses Menjadi Hafizh Al-Qur'an Da'iyah, Jakarta: Markaz Al-Qur'an, 2015..

As-Sirjani, Raghib, Mukjizat Menghafal Al-Qur'an, Jakarta: Zikrul Hakim, 2009.

Azhim, Irfan Abdul, Agar Bacaan Qur'an Anda Tak Sia-Sia, Solo: Pustaka Iltizam, 2009.

Az-Zamawi, Yahya Abdul Fattah, Revolusi Menghafal Al-Qur'an, Solo: Insan Kamil, 2018.

Baduwailan, Ahmad Bin Salim, Cara Mudah dan Cepat Hafal Al-Qur'an, Solo: Kiswah Media, 2014.

Balai Litbang Agama Jakarta, Membumikan Peradaban Tahfidz Al-Qur'an, Jakarta: Balai Penelitian dan Pengembangan Agama Jakarta.

Dakir, Perencanaan Dan Pengembangan Kurikulum, Jakarta: Rineka Cipta, 2010.

Hamalik, Oemar, Dasar-dasar Pengembangan Kurikulum, Bandung: PT Remaja Rosdakarya, 2007.

H. Haryono dan Amirul Hadi, Metodologi Penelitian Pendidikan, Bandung: Pustaka Setia, 2005.

Idi, Abdullah, Pengembangan Kurikulum Teori dan Praktik, Jakarta: Rajawali Pers, 2016.

Kamus Besar Bahasa Indonesia Online, kbbi.web.id/, diakses tanggal 27 April 2019.

Makhyaruddin, Deden M, Rahasia Nikmatnya Menghafal Al-Qur'an, Jakarta: Noura Books, 2013.

Muhammad, Ahsin Sakho, Menghafal Al-Qur'an, Jakarta: Qaf, 2018.

Muhaimin, H, dkk, Pengembangan Model Kurikulum Tingkat Satuan Pendidikan Pada Sekolah \& Madrasah, Jakarta: Rajawali Pers, 2009.

Mulyasa, E. Manajemen Berbasis Sekolah, Bandung: PT Remaja Rosdakarya, 2012.

Rauf, Abdul Aziz Abdul, Kiat Sukses Menjadi Hafizh Qur'an Dai'yah, Bandung: PT Syamil Cipta Media, 2004.

35 | Fatimah dan Sri Tuti Rahmawati: Implementas Muatan Lokal dalam, ... 
Sa'dulloh, 9 Cara Cepat Hafal Al-Qur'an, Jakarta: Gema Insani, 2008.

Shihab, M. Quraish. Membumikan Al-Qur'an: Fungsi dan Peran Wahyu Dalam Kehidupan Masyarakat, Bandung: PT. Mizan Pustaka, 2007

Sukmadinata, Nana Syaodih, Metode Penelitian Pendidikan. Bandung: PT Remaja Rosdakarya, 2011.

Suryabrata, Sumadi, Metodologi Penelitian, Jakarta: PT. Raja Grafindo Persada, 2011.

Usman, Nurdin, Konteks Implementasi Berbasis Kurikulum, Jakarta: PT Raja Grafindo Persada, 2002.

Wahid, Wiwi Alawiyah, Cara Cepat \& Mudah Hafal Al-Qur'an, Yogyakarta: Kaktus, 2018.

Zamani, Zaki dan Syukron Maksum, Metode Cepat Menghafal Al-Qur'an, Yogyakarta: Al Barokah, 2014.

Zen, Muhaimin, Tahfidz Al-Qur'an Metode Lauhun, Jakarta: Transpustaka, 2013

36 | Fatimah dan Sri Tuti Rahmawati: Implementas Muatan Lokal dalam, ... 